References

1. Levine, M. M., Nalin, D. R., Craig, J. P., Hoover, D., Bergquist, E. J Waterman, D., Holley, H. P., Hornick, R. B., Pierce, N. P., and Libonati, J. P. 1979. Immunity to cholera in man: relative role of antibacterial versus antitoxic immunity. Trans. Roy. Soc. Trop. Med. Hyg. 73:3-9.

2. Levine, M. M. 1980. Immunity to cholera as evaluated volunteers, pp. 195-203. In Cholera and Related Diarrhoeas. O. Ouchterlony and J. Holmgren (eds.), Karger, Basel.

3. Levine, M. M., Black, R. E., Clements, M. L., Cisneros, L., Nalin, D. R., and Young, C. R. 1981. Duration of infection-derived immunity to cholera. J. Infect. Dis. 143:818-820.

4. Levine, M. M., Black, R. E., Clements, M. L., Nalin, D. R., Cisneros L., and Finkelstein, R. A. 1981. Volunteer studies in development of vaccines against cholera and enterotoxigenic Escherichia coli: a review, pp. 449-459. In Acute Enteric Infections in Children: New Prospects for Treatment and Prevention. T. Holme, J. Holmgren, M. H. Merson, and R. Mollby (eds.), Elsevier, Amsterdam.

5. Glass, R. I., Becker, S., Huq, M. I., Stoll, B. J., Khan, M. U., Merson M. H., Lee, J. V., and Black, R. E. 1982. Endemic cholera in rural Bangladesh, 1966-1980. Am. J. Epidemiol. 116:959-970.

6. Kleid, D. G., Yansura, D., Small, B., Dowbenko, D., Moore, D. M Grubman, M. J., McKercher, P. D., Morgan, D. O., Robertson, B. H. and Bachrach, H. L. 1981. Cloned viral protein vaccine for foot-andmouth disease: responses in cattle and swine. Science 214:1125-1129.

7. Bachrach, H. L. 1982. Recombinant DNA technology for the preparation of subunit vaccines. J. Am. Vet. Med. Assoc. 181:992-999.

8. Levine, M. M., Kaper, J. B., Black, R. E., and Clements, M. L. 1983 New knowledge on pathogenesis of bacterial enteric infections as applied to vaccine development. Microbiol. Rev. 47:510-550.

9. Curlin, G., Levine, R., Azia, K. M. A., Mizanur Rahman, A. C. M., and Verway, W. F. 1975. Field trial of cholera toxoid, pp. 314-329. Proc. 11 th Joint Conference on Cholera, Washington, D.C.

10. Noriki, H. 1976. Evaluation of toxoid field trials in the Philippines, pp 302-310. Proc. 12th Joint Conference on Cholera, Tokyo.

11. Lockman, H. and Kaper, J. B. 1983. Nucleotide sequence analysis of the $\mathrm{A}_{2}$ and $\mathrm{B}$ subunits of Vibrio cholerae enterotoxin. J. Biol. Chem. 258:13722-13726.

12. Kaper, J. B., Moseley, S. L., and Falkow, S. 1981. Molecular characterization of environmental and nontoxinogenic strains of Vibrio cholerae Infect. Immun. 32:661-667.

13. Mekalanos, J. J. 1983. Duplication and amplification of toxin genes in Vibrio cholerae. Cell 35:253-263.

14. Gennaro, M. L. and Greenway, P. J. 1983. Nucleotide sequences within the cholera toxin operon. Nucl. Acids. Res. 11:3855-3861.

5. Mekalanos, J. J., Swartz, D. J., Pearson, G. D. N., Harford, N. Groyne, F., and de Wilde, M. 1983. Cholera toxin genes: nucleotide sequence deletion analysis, and vaccinc development Nature 306:551-557.

16. Gill, D. M. 1976. The arrangement of subunits in cholera toxin. Biochemistry 15:1242-1248.

17. Gill, D. M. and Meren, R. 1978. ADP-ribosylation of membrane proteins catalyzed by cholera toxin: basis of the activation of adenylate cyclase. Proc. Natl. Acad. Sci. U.S.A. 75:3050-3054

18. Ruvkun, G. R. and Ausubel, F. M. 1981. A general method for sitedirected mutagenesis in prokaryotes. Nature 289:85-88.

19. Levine, M. M., Black, R. E., Clements, M. L., Young, C. R., Lanata, C. Sears, S., Honda, ' $Г$., and Finkelstein, R. 1983. Texas Star-SR: attenuated Vibrio cholerae oral vaccine candidatc. Devclop. Biol. Stand. 53:59-65

20. Ditta, G., Stanfield, S., Corbin, D., and Helinski, D. R. 1980. Broad host range DNA cloning system for gram-negative bacteria: construction of a gene bank of Rhizobium meliloti. Proc. Natl. Acad. Sci. U.S.A. 77:7347-7351.

21. Miller, J. M. 1972. Experiments in molecular genetics. Cold Spring Harbor Laboratory, Cold Spring Harbor, New York.

22. Brenner, D. J., Fanning, G. R., Johnson K. E., Citarella, R. V., and Falkow S. 1969. Polynucleotide sequence relationships among members of Enterobacteriaceae. J. Bacteriol. 98:637-650.

23. Birnboim, H. C. and Doly, J. 1979. A rapid alkaline extraction procedure for screening recombinant DNA. Nucl. Acids. Res. 7:15131523.

24. Maniatis, T., Fritsch, E. F., and Sambrook, J. 1982. Molecular cloning. Cold Spring Harbor Laboratory, Cold Spring Harbor, New York.

25. Bolivar, F. 1978. Construction and characterization of new cloning vehicles. III. Derivatives of plasmid pBR322 carrying unique Eco RI sites for selection of Eco RI generated recombinant DNA molecules. Gene 4:121-136.

26. Bolivar, F., Rodriguez, R. L., Green, P. J., Betlach, M. C., Heynecker, H. L., Boyer, H. W., Crosa, J. M., and Falkow, S. 1977. Construction and characterization of new cloning vehicles. II. A multipurpose cloning system. Gene 2:95-113.

27. Southern, E. M. 1975. Detection of specific sequences among DNA fragments separated by gel electrophoresis. J. Mol. Biol. 98:503-517.

28. Maniatis, T., Jeffrey, A., and Kleid, D. G. 1975. Nucleotide sequence of the rightward operator of phage lambda. Proc. Natl. Acad. Sci. U.S.A. 72:1184-1188.

29. Sack, D. A. and Sack, R. B. 1975. Test for enterotoxigenic Escherichia coli using Y1 adrenal cells in miniculture. Infect. Immun. 11:334-336.

30. Sack, D. A., Huda, S., Neogi, P. K. B., Daniel, R. R., and Spira, W. M 1980. Microtiter ganglioside enzyme-linked immunosorbent assay for Vibrio and Escherichia coli heat-labile enterotoxins and antitoxin. J Clin. Microbiol. 11:35-40.

\title{
ENZYME MEMBRANE IMMUNOASSAY (EMIA)
}

J. C. Braman, R. J. Broeze, D. W. Bowden, A. Myles, T. R. Fulton, M. Rising, J.

Thurston, F. X. Cole, and G. F. Vovis

Department of Molecular Biology and Immunology, Collaborative Research, Inc., Lexington, MA 02173

Homogeneous enzyme membrane immunoassays (EMIAs) have been developed for thyroxine $\left(T_{4}\right)$ and human immunoglobulin G (IgG). Liposomes tagged with $\mathbf{T}_{4}$ and containing alkaline phosphatase were used as a model system for optimization of (a) liposome membrane attack in the presence of $T_{4}$ antiserum and guinea pig complement and (b) subsequent measurement of unmasked enzyme activity. Using a one-incubation-step format, the concentration of $T_{4}$ in human serum samples was measured. Alkaline phosphatase activity was inversely proportional to the concentration of $T_{4}$ in the sample. The $T_{4}$ values obtained by EMIA correlated well with values obtained by radioimmunoassay $(r=0.96)$. Likewise, there was an excellent correlation between IgG values obtained by EMIA and radialimmunodiffusion or nephelometry $(r=0.99)$.
Liposomes are spherical, membranous vesicles often prepared from phospholipids, sterols, and charged amphiphiles. Depending on the method of preparation, these vesicles are either multilamellar or unilamellar and have a variety of sizes. Because liposomes can be engineered to mimic the properties of biological membranes, they have been used as a model system to study the mechanism of complement-mediated immune cytolysis ${ }^{1}$.
For example, Haxby et al. ${ }^{2}$ demonstrated that liposomes prepared from sheep erythrocyte membranes and containing glucose as a marker could be damaged immunospecifically in the presence of rabbit anti-sheep erythrocyte serum and guinea pig complement. The extent and rate of glucose loss from these damaged liposomes was found to be dependent upon the amount of Forssman hapten incorporated into the vesicles, the concentration of 
TABLE 1 Effect of reaction components on complement-mediated $\mathrm{T}_{4}$ liposome damage. Reaction mixtures contained the following components: a. $0.1 \mathrm{ml}$ Buffer A (see Experimental Protocol), $0.1 \mathrm{ml}$ complement-liposome cocktail (made by diluting guinea pig complement 1:15 in Buffer $\mathrm{A}$ and adding $0.5 \mu \mathrm{l}$ liposome suspension per $0.1 \mathrm{ml}$ of this solution), and $0.05 \mathrm{ml}$ sheep anti- $\mathrm{T}_{4}$ serum diluted 1:75 in Buffer A; b. lacked $\mathrm{T}_{4}$ antiserum and c. lacked complement; $d$. contained guinea pig complement treated at $56^{\circ} \mathrm{C}$ for 30 minutes prior to use; e. contained $100 \mathrm{ng}$ of $\mathrm{T}_{4}(0.1 \mathrm{ml}$ of a $1000 \mathrm{ng} / \mathrm{ml}$ stock solution in Buffer A) in place of $0.1 \mathrm{ml}$ of Buffer $\mathrm{A}$. The reaction mixtures were incubated at $37^{\circ} \mathrm{C}$ for 20 minutes, then $1 \mathrm{ml}$ of $3.8 \mathrm{mM}$ pNPP in Buffer B (see Experimental Protocol) was added and the reactions incubated an additional 15 minutes at $37^{\circ} \mathrm{C}$. The reactions were terminated by addition of $1 \mathrm{ml} 0.5 \mathrm{M} \mathrm{NaOH}$ and the absorbance at $410 \mathrm{~nm}$ was recorded.

Reaction Components

a. liposomes, $\mathrm{T}_{4}$ antiserum, complement

b. minus $\mathrm{T}_{4}$ antiserum

c. minus complement

d. heat treated complement

e. plus $100 \mathrm{ng} \mathrm{T}_{4}$

1.64

0.09

0.09

0.09

0.09

Forssman antiserum, and active complement in the reaction mixture 3 .

As a result of these observations, liposome-based immunoassays were developed to quantitate analytes in biological fluids ${ }^{4-8}$. For example, Wei et al. ${ }^{4}$ produced an immunoassay that measured glycolipids in aqueous media. In this system, Forssman hapten was incorporated into liposomes prepared from dipalmitoylphosphatidylcholine, cholesterol, and dicetylphosphate. After reaction with Forssman antiserum and guinea pig complement, the liposomes released the spin label marker tempocholine bromide. Free Forssman hapten added to the reaction competed with hapten on the bilayer of the liposome for Forssman antibody molecules in the mixture. As the concentration of free Forssman glycolipid increased, the release of trapped marker decreased.

We have extended these concepts to develop a homogeneous, one-incubation-step, colorimetric immunoassay system. With this system, an enzyme marker is encapsulated within liposomes and serves as a signal generator' ${ }^{9}$. We call this system EMIA (Enzyme Membrane ImmunoAssay). The assay is amenable to measuring haptens or macromolecular antigens. In this paper, we describe an EMIA for the thyroid hormone thyroxine $\left(\mathrm{T}_{4}\right)$ and one for the immunoglobulin IgG.

\section{RESULTS}

EMIA is based on the ability of guinea pig complement to damage antigen-tagged liposomes when immunospecific antigen-antibody complexes are formed on the surface of the vesicles ${ }^{1}$. Damage to the liposome membrane is monitored by measuring unmasked alkaline phosphatase activity. Consequently, initial experiments were designed to investigate the conditions for these reactions to take place. $\mathrm{T}_{4}$-liposomes were chosen for these experiments. During an initial incubation (Step 1), complement-mediated damage to $T_{4}$-liposomes occurred in the presence of $T_{4}$ aitiserum. A second incubation (Step 2) was then performed in a high ionic strength buffer. This buffer inhibited complement activity (data not shown) and permitted measurement of unmasked enzyme activity. The enzyme activity observed as the result of complementmediated damage to the liposomes was defined as the
TABLE 2 Location of enzyme activity after complement-mediated liposome damage. Complement-mediated damage of T4 liposomes (Step 1) was carried out in the presence and absence of $\mathrm{T}_{4}$ antiserum as described in Table 1 for reactions $\mathrm{a}$ and $\mathrm{b}$ in conical plastic tubes. Liposomes were then separated from the other reaction components by centrifugation at $10,000 \times \mathrm{g}$ for 10 minutes at $4^{\circ} \mathrm{C}$. The supernatant was carefully removed and the liposome pellet was resuspended in a volume of Buffer A equal to the volume of the supernatant. $0.10 \mathrm{ml}$ samples were taken from each fraction and tested for alkaline phosphatase activity as described in Table 1.

\begin{tabular}{lcc}
\hline & \multicolumn{2}{c}{ (S) } \\
\cline { 2 - 3 } & Supernatant & Pellet \\
\hline$-\mathrm{T}_{4}$ Antiserum & 0.07 & 0.06 \\
$+\mathrm{T}_{4}$ Antiserum & 0.16 & 1.49 \\
& & \\
\hline
\end{tabular}

signal, (S). The enzyme activity observed in the absence of complement-mediated liposome damage was defined as the intrinsic background, (B).

Conditions required for liposome damage. $\mathrm{T}_{4}$-liposomes were susceptible to complement-mediated membrane damage when incubated in the presence of $T_{4}$ antiserum and guinea pig complement (Table 1). The liposomes were resistant to damage when $\mathrm{T}_{4}$ antiserum or complement were omitted from the reaction mixture, heat inactivated complement was substituted for active complement, or $100 \mathrm{ng}$ of $\mathrm{T}_{4}$ was added to the reaction mixture (Table 1). When liposomes lacking $T_{4}$ were incubated in the presence of $\mathrm{T}_{4}$ antiserum and complement, (S) and (B) values were identical (data not shown). These results demonstrated that antigen-antibody complexes must form on the surface of the liposome before complement-mediated membrane damage can occur $^{3,10,11}$

Following complement-mediated membrane damage, alkaline phosphatase molecules can either remain within the damaged liposomes or can be released into the external medium. To discriminate between these two possibilities, we allowed complement-mediated damage of $T_{4}$ liposomes to occur (Step 1), then separated the damaged liposomes from the medium by centrifugation. The liposome pellet and the liposome-free supernatant were then tested for alkaline phosphatase activity by the addition of pNPP. As shown in Table 2, little enzyme activity was present in either the supernatant or liposome pellet fractions when $\mathrm{T}_{4}$ antiserum was absent from the reaction mixture. When $\mathrm{T}_{4}$ antiserum was added, the majority of the unmasked enzyme activity remained associated with the liposome pellet. Less than $6 \%$ of the unmasked enzyme activity was found in the supernatant fraction. Control experiments demonstrated that alkaline phosphatase does not bind nonspecifically to the liposome surface (data not shown). These results indicate that with the conditions used in EMIA, encapsulated enzyme remains within the liposomes after complement-mediated damage.

Kinetics of Step 1 and Step 2. The kinetics of complement-mediated $\mathrm{T}_{4}$ liposome damage (Step 1) and the subsequent measurement of unmasked alkaline phosphatase activity (Step 2) are shown in Figure 1. For Step 1, reactions were performed with concentrations of complement and $T_{4}$ antiserum that produced maximum (S) values. An initial lag in the appearance of enzymatic activity was observed (Fig. 1A). A similar lag has been reported in the hemolytic assay for complement activity ${ }^{12}$. Following the lag period, (S) values increased until at 30 

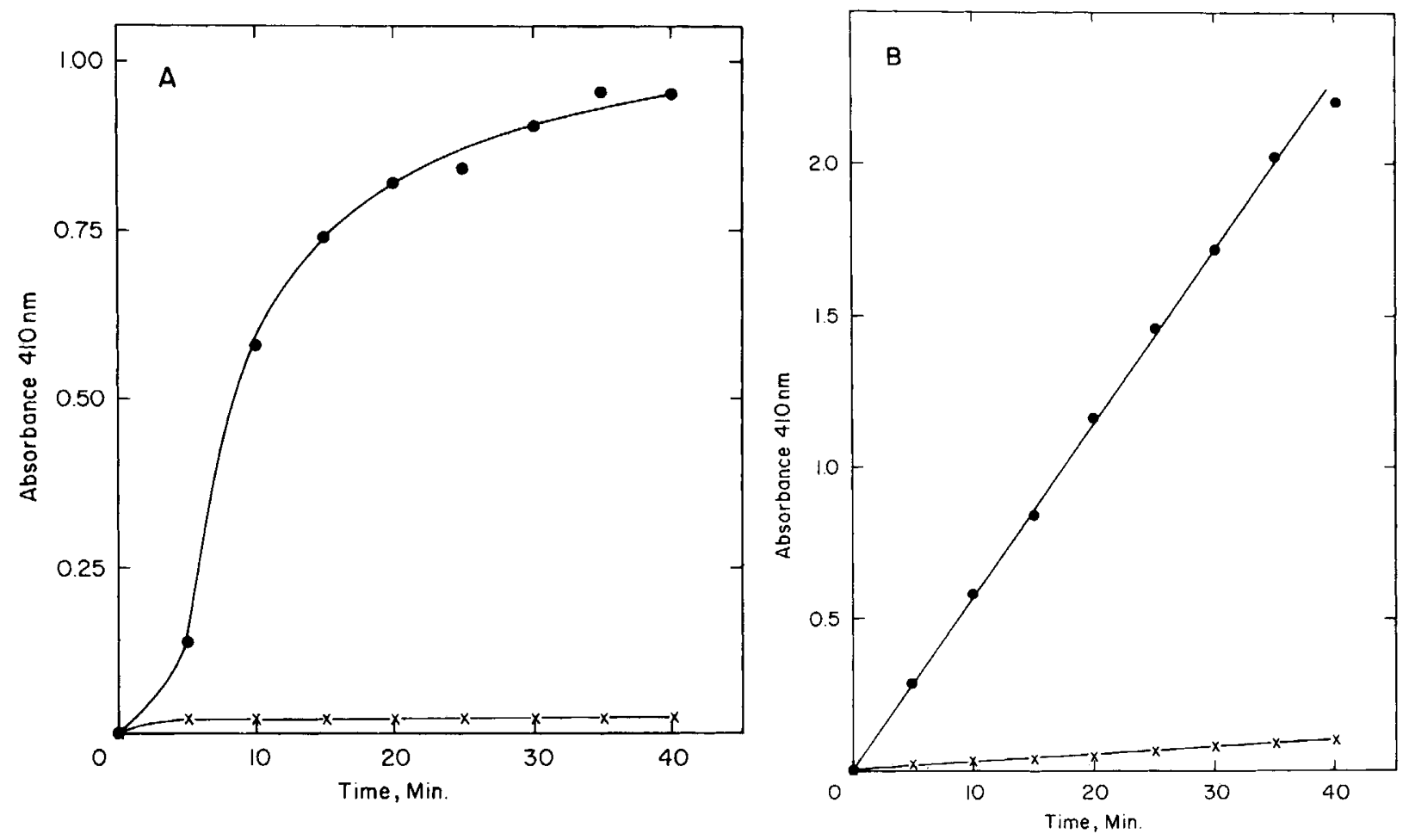

Fleure 1 Effect of Step 1 and Step 2 incubation time on pNP production. A. Step 1 incubation time. Reaction mixtures contained the same components to generate $(S)(-\mathbf{O})$ and (B) $(\mathrm{X}-\mathrm{X})$ values as described in Table 1 a and e, respectively, and were incubated for the indicated time periods at $37^{\circ} \mathrm{C}$. One $\mathrm{ml}$ of $3.8 \mathrm{mM}$ pNPP in Buffer B was added and the solutions were incubated for 15 minutes at $37^{\circ} \mathrm{C}$. The reactions were terminated and the absorbance values recorded as

described in Table 1. B. Step 2 incubation time. Reaction mixtures were prepared to generate (S) and (B) values as described in Table 1 a and e, respectively, and were incubated for 30 minutes at $37^{\circ} \mathrm{C}$. One $\mathrm{ml}$ of $3.8 \mathrm{mM}$ pNPP in Buffer B was added and the reactions were incubated at $37^{\circ} \mathrm{C}$ for the indicated time periods. The reactions were terminated and the absorbance values recorded as described in Table 1.

minutes complement-mediated liposome damage was essentially complete. For Step 2, pNPP conversion to pNP was linear for at least 35 minutes at $37^{\circ} \mathrm{C}$ (Fig. 1B). This result indicated that $\mathrm{pNPP}$ was not limiting in the assay. (S) values for complement-damaged liposomes were generally $80-90 \%$ of the values obtained with detergent-lysed liposomes (data not shown). (B) values remained consistently low throughout the time course of these experiments, suggesting that little complement-independent membrane damage occurred under these conditions and that alkaline phosphatase activity was negligible in the guinea pig serum that served as the source of complement (see also Table 1).

Optimization of Step 1 . The affinity of antibody molecules for their antigens and the hemolytic activity of complement can be altered by changes in $\mathrm{pH}$ and ionic strength $^{12,13}$. In addition, guinea pig complement requires $\mathrm{Mg}^{++}$and $\mathrm{Ca}^{++}$ions for optimal activity ${ }^{12}$. Since Step 1 involved $\mathrm{T}_{4}$ antibody binding to liposomes followed by complement-mediated damage to the vesicles, we optimized the composition of the buffer for these events to occur.

Figure 2 represents (S), (B), and (S)-(B) values produced when Tris buffers of varying ionic strengths were used in Step 1. (B) values were elevated with Tris buffers having ionic strength values between 0.02 and $0.15 \mathrm{M}$ ( 0.09 to 0.35 osmolar). This may be the result of osmotic damage to the liposomes, since they were routinely prepared in PBS (0.33 osmolar). (B) values were low when

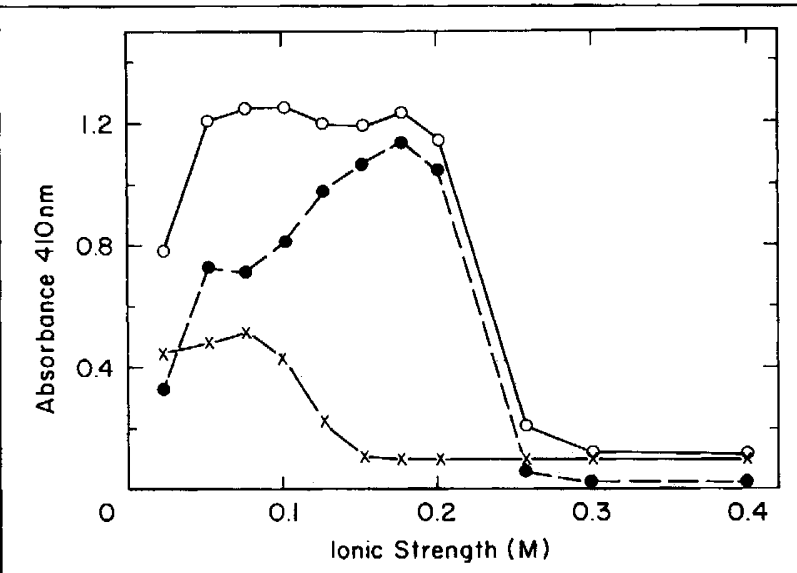

FieUne 2 Effect of ionic strength on complement-mediated $\mathrm{T}_{4}$ liposome damage. The assay components used to measure each $(\mathrm{S})(\mathrm{O}-\mathrm{O})$ and $(\mathrm{B})(\mathrm{X}-\mathrm{X})$ value were prepared in $0.02 \mathrm{M}$ Tris, $0.5 \mathrm{mM} \mathrm{MgCl}_{2}, 0.15 \mathrm{mM} \mathrm{CaCl}_{2}, 3.1 \mathrm{mM} \mathrm{NaN}$, pH 7.2 at $37^{\circ} \mathrm{C}$. The ionic strength of each buffer was varied with $\mathrm{NaCl}$ between 0.023 and $0.422 \mathrm{M}$. Reaction mixtures contained the same components as described in Table $1 \mathrm{a}$ and $\mathrm{e}$. The reaction mixtures were incubated for 30 minutes at $37^{\circ} \mathrm{C}$. One $\mathrm{ml}$ of $3.8 \mathrm{mM}$ pNPP in Buffer $\mathrm{B}$ was then added and the reactions were incubated an additional 20 minutes at $37^{\circ} \mathrm{C}$. The reactions were terminated and the absorbance values recorded as described in Table 1. (S)-(B) values are represented as (-) 
TABLE 3 Effect of buffer composition on complement and antibody requirements for $\mathrm{T}_{4}$ EMIA. a. Reaction mixtures contained components prepared in Buffer $\mathrm{A}$ and $\mathrm{Buffer} \mathrm{C}$ as described in Table la. Guinea pig complement was diluted with Buffer $\mathrm{A}$ or $\mathrm{C}$ between 1:300 and 1:5 to prepare the complement-liposome cocktails. The reaction mixtures were incubated and processed as described in Figure 2. The (S) values were plotted as a function of guinea pig complement dilution and the volume of complement required to achieve a (S) of 0.9 was calculated. b. Reaction mixtures contained components prepared in Buffer $\mathrm{A}$ or $\mathrm{C}$ as described in Table 1a. Reactions were initiatèd by the addition of $0.05 \mathrm{ml}$ sheep anti- $\mathrm{T}_{4}$ serum diluted between 1:2000 and 1:75 in Buffer $\mathrm{A}$ or C. The (S) values were plotted as a function of the $T_{4}$ antiserum dilution and the volume of antiserum required to achieve a $(\mathrm{S})$ of 0.9 was calculated.

\begin{tabular}{|c|c|c|}
\hline & Buffer A & Buffer C \\
\hline $\begin{array}{l}\text { a. Complement }(\mu \mathrm{l}) \text { re- } \\
\text { quired to generate } \\
\text { a }(S) \text { of } 0.9\end{array}$ & 3.6 & 1.1 \\
\hline $\begin{array}{l}\text { b. } \mathrm{T}_{4} \text { antiserum }(\mu \mathrm{l}) \\
\text { required to gener- } \\
\text { ate a }(\mathrm{S}) \text { of } 0.9\end{array}$ & 0.17 & 0.10 \\
\hline
\end{tabular}

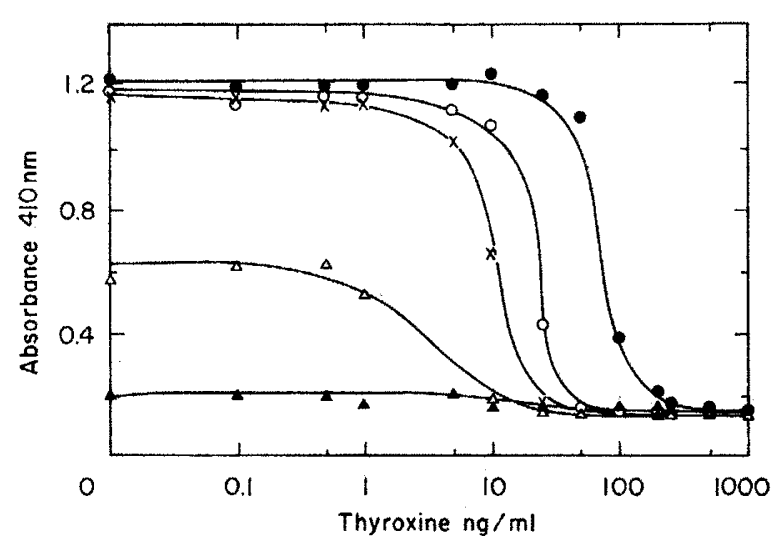

FlouRE $3 \mathrm{~T}_{4}$ EMIA standard curves-sensitivity as a function of $\mathrm{T}_{4}$ anti-serum concentration. Reaction mixtures contained the following components: $0.1 \mathrm{ml}$ various $T_{4}$ solutions, the concentrations of which are noted on the abcissa in $\mathrm{ng} / \mathrm{ml} ; 0.1 \mathrm{ml}$ complement cocktail (guinea pig complement diluted 1:15 in Buffer $\mathrm{C}$ containing $1.0 \mu \mathrm{l}$ of concentrated liposome suspension per $0.1 \mathrm{ml}$ solution), and $0.05 \mathrm{ml}$ of sheep anti- $\mathrm{T}_{4}$ serum at dilutions of $1: 2000(\boldsymbol{\Delta}-\mathbf{A}), 1: 1500(\Delta-\Delta), 1: 1000(X-X)$, 1:750 (O-O), or $1: 300(-)$ in Buffer $\mathrm{C}$. The reaction mixtures were incubated and processed as described in Figure 2.

TABLE 4 Measurement of $T_{4}$ in pooled human serum spiked with $\mathrm{T}_{4}$. Pooled human serum was spiked with $\mathrm{T}_{4}$ and dilutions subsequently made with $0.9 \% \mathrm{NaCl}$. The $\mathrm{T}_{4}$ content of each sample was measured using the one-incubation-step protocol outlined in Figure 4.

\begin{tabular}{ccc}
\hline $\begin{array}{c}\text { Dilution of } \\
\text { spiked serum }\end{array}$ & $\begin{array}{c}\mathbf{T}_{\mathbf{4}} \text { measured } \\
\text { by EMIA } \\
(\mathbf{n g} / \mathbf{m l})\end{array}$ & $\begin{array}{c}\mathbf{T}_{\mathbf{4}} \text { calculated } \\
\text { in spiked } \\
\text { serum }(\mathbf{n g} / \mathbf{m l})\end{array}$ \\
\hline Undiluted & 180 & 180 \\
$1: 2$ & 94 & 188 \\
$1: 4$ & 47 & 188 \\
$1: 8$ & 22 & 176 \\
& & \\
\hline
\end{tabular}

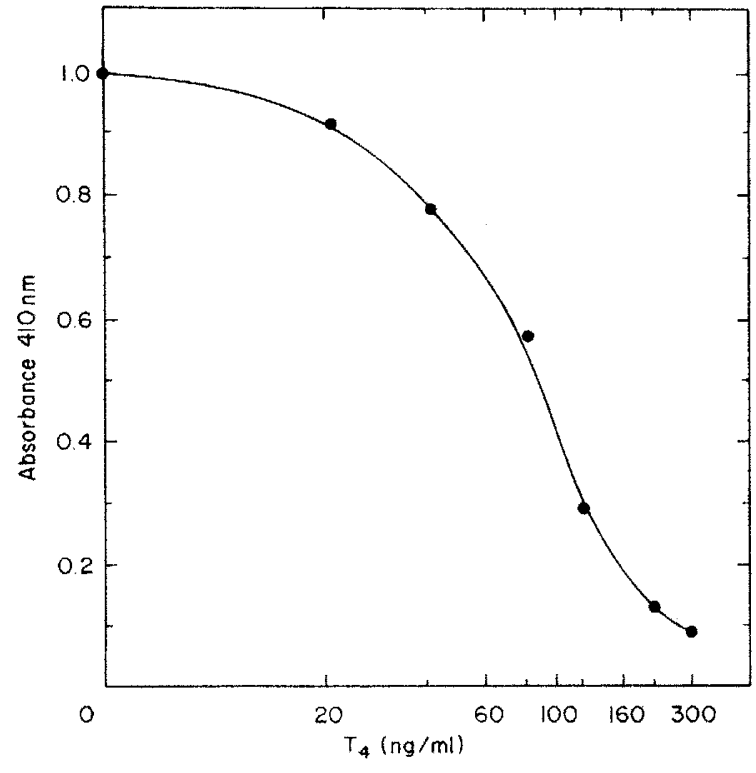

Flourf 4 One incubation step $\mathrm{T}_{4}$ EMIA. $0.2 \mathrm{ml}$ of $0.08 \mathrm{~N} \mathrm{HCl}$ was distributed into test tubes containing $0.025 \mathrm{ml}$ of $\mathrm{T}_{4}$ standard at the concentrations indicated on the abcissa in $\mathrm{ng} / \mathrm{ml} .0 .7 \mathrm{ml}$ of a complement-enzyme substrate-liposome cocktail (prepared by diluting $0.5 \mathrm{ml}$ guinea pig complement with $11 \mathrm{ml}$ of Buffer $\mathrm{C}$ containing $8.6 \mathrm{mM}$ pNPP and $0.015 \mathrm{ml}$ of liposome suspension) was added to each tube. This was followed by the addition of $0.1 \mathrm{ml}$ of sheep anti- $T_{4}$ serum diluted 1:500 in Buffer $C$. The reaction mixtures were incubated at $37^{\circ} \mathrm{C}$ for 30 minutes. The reactions were terminated with $1 \mathrm{ml}$ of $0.5 \mathrm{~N} \mathrm{NaOH}$ and the absorbance at $410 \mathrm{~nm}$ determined.

liposomes were incubated in Tris buffers having ionic strengths between 0.15 and $0.4 \mathrm{M}$. Optimal ionic strength for complement-dependent lysis of antibody-sensitized liposomes occurred between 0.15 and $0.2 \mathrm{M}$, as demonstrated by the high $(\mathrm{S})$ - $(\mathrm{B})$ values. However, between 0.20 and $0.25 \mathrm{M}$ a decline in $(\mathrm{S})-(\mathrm{B})$ values occurred. This result is consistent with the inactivation of complement activity at high ionic strength ${ }^{12}$.

Complement-dependent damage to $\mathrm{T}_{4}$ liposomes was also optimized with respect to $\mathrm{pH}$, Tris, $\mathrm{Mg}^{++}$, and $\mathrm{Ca}^{++}$ concentrations. (S) and (B) values were generated for buffers in concentrations from 0.01 to $0.3 \mathrm{M}$ Tris, 0 to $0.25 \mathrm{mM} \mathrm{MgCl}_{2}, 0$ to $0.5 \mathrm{mM} \mathrm{CaCl}_{2}$, and $\mathrm{pH}$ from 7 to 9 . The ionic strength of the buffers was maintained at $0.16 \mathrm{M}$ with $\mathrm{NaCl}$ in each of the experiments. Buffer $\mathrm{C}$ (see Experimental Protocol) was found to be optimal for the reactions of Step 1 (data not shown). The superiority of this buffer was demonstrated when complement and $T_{4}$ antiserum were titrated in the presence of $1 \mu \mathrm{l}$ of $T_{4}$ liposomes, using either Buffer A (see Experimental Protocol), the original buffer used for $\mathrm{EMIA}^{9}$, or Buffer C. As shown in Table $3,3.6 \mu$ l of complement were required to generate an arbitrary (S) of 0.9 in Buffer A compared to $1.1 \mu \mathrm{l}$ of complement in Buffer $\mathrm{C}$. In addition, $42 \%$ less $\mathrm{T}_{4}$ antiserum was required to produce an (S) of 0.9 in Buffer $C$ than in Buffer $A$.

Influence of $T_{4}$ antiserum and exogenous $T_{4}$ on the EMIA system. The measurement of antigen concentration by EMIA is based on the suppression of complementmediated damage to liposomes, which occurs when progressively fewer antigen-antibody complexes form on the liposome surface as the antigen concentration increases. 


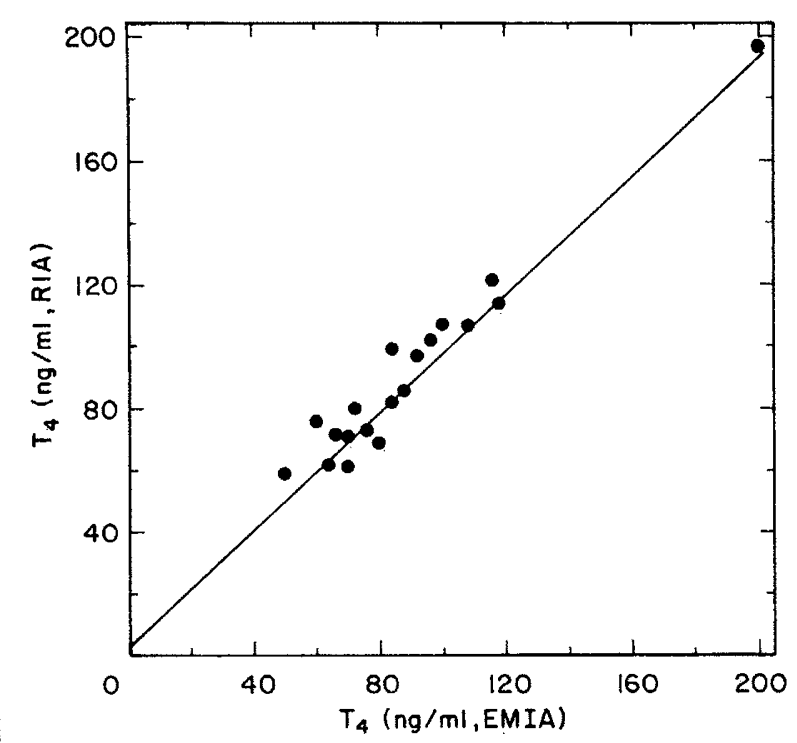

FICURE 5 Correlation between EMIA and RIA. Serum samples were obtained from a local hospital and stored at $4^{\circ} \mathrm{C}$ until use. The samples and $T_{4}$ standards $(0.025 \mathrm{ml}$ each) were assayed as described in the legend to Figure 4 . The $T_{4}$ standards were used to construct a standard curve, which was employed to determine the $\mathrm{T}_{4}$ concentrations in the serum samples. The $T_{4}$ concentration in each serum sample was also measured by RIA according to the protocol provided by the manufacturer (Clinical Assays). The $\mathrm{T}_{4}$ concentration measured in each serum sample by EMIA is plotted on the abcissa and that by RIA on the ordinate.

In addition, when progressively lower concentrations of antiserum are added to the system, less antigen is required to prevent antibody binding to the liposome surface; consequently, less antigen can be detected. These principles are demonstrated in Figure 3. At a fixed concentration of $\mathrm{T}_{4}$ antiserum, (S) declined with increasing concentrations of $T_{4}$. As less antiserum was added to reaction mixtures, less $\mathrm{T}_{4}$ was required to suppress (S) and the midpoint of the standard curve shifted to lower $T_{4}$ concentrations. The sensitivity of the assay was therefore increased as the $T_{4}$ antiserum concentration decreased.

One-incubation-step assay of total $T_{4}$ in human serum. Complement-mediated damage of $\mathrm{T}_{4}$-liposomes and the subsequent measurement of unmasked enzyme activity were combined in a single incubation step because the activity of bacterial alkaline phosphatase was found to be compatible with Buffer $\mathrm{C}$ (data not shown). Complement, liposomes, and pNPP were mixed with $\mathrm{T}_{4}$ standards at concentrations ranging from 0 to $1000 \mathrm{ng} / \mathrm{ml}(0-25 \mathrm{ng}$ total) in Buffer $C$. $T_{4}$ antiserum was added to initiate complement-mediated damage to the liposomes and the reactions were allowed to proceed for 30 minutes. Standard curves similiar to those using the two-incubation-step format were generated (Fig. 4).

By adjusting the concentration of the $T_{4}$ antiserum appropriately, the standard curve was positioned in order to quantitate $\mathrm{T}_{4}$ in human serum $\left(45-115 \mathrm{ng} / \mathrm{ml}^{14}\right) . T_{4}$ was released from endogenous thyroxine-binding globulins by pretreatment of the serum with $0.2 \mathrm{ml}$ of $0.08 \mathrm{~N}$ $\mathrm{HCl}^{15}$. This treatment also completely inactivated any endogenous phosphatase activity present in the test sample (data not shown). $T_{4}$ values for 19 individual serum

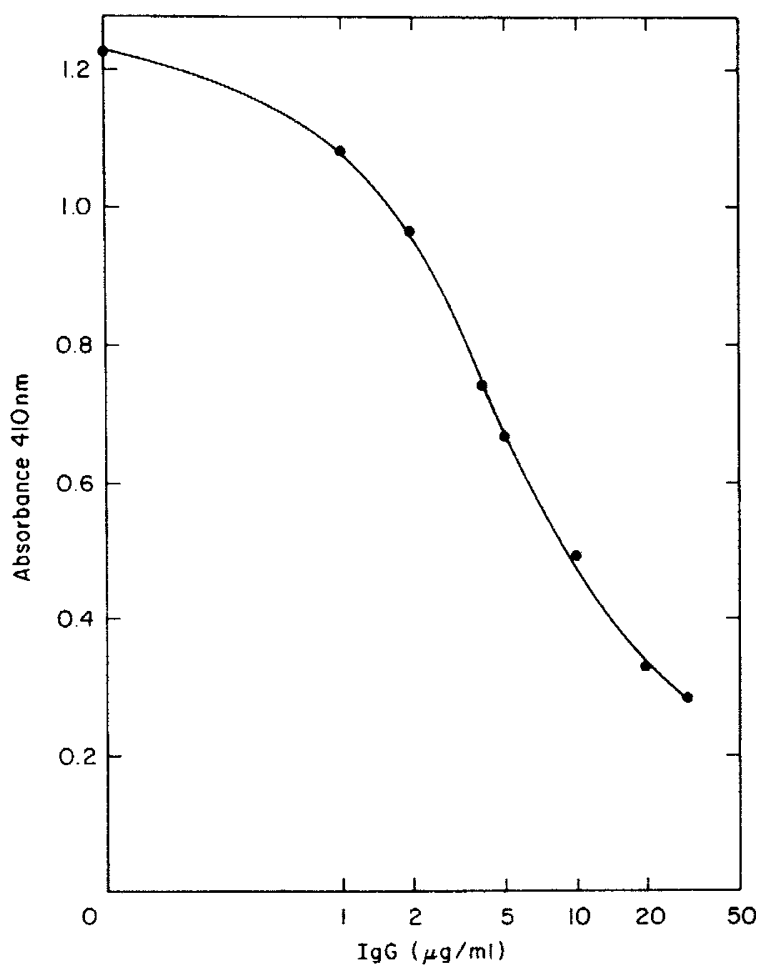

FleURE 6 One-incubation-step IgG EMIA. (S) was generated at various IgG concentrations according to the following procedure. All reaction components were prepared in Buffer D (see Experimental Protocol); human IgG standards $(0.1 \mathrm{ml}$, at the concentrations shown on the abcissa) and human $\operatorname{IgM}(0.1 \mathrm{ml}$, $0.01 \mathrm{mg}$ ), were distributed into test tubes. $0.4 \mathrm{ml}$ of $19 \mathrm{mM}$ pNPP was added followed by $0.2 \mathrm{ml}$ of guinea pig complement (diluted $1: 8$ ) and $0.2 \mathrm{ml}$ of anti-IgG serum. One $\mu \mathrm{l}$ of $\mathrm{F}\left(\mathrm{ab}^{\prime}\right)_{2}$-liposomes was added and the reaction mixtures were incubated at $37^{\circ} \mathrm{C}$ for 30 minutes. One $\mathrm{ml}$ of $0.5 \mathrm{~N} \mathrm{NaOH}$ was added to terminate the reactions and the absorbance at 410 nm determined.

samples were determined by EMIA and radioimmunoassay (RIA). Figure 5 shows that there was excellent agreement between the two tests. The correlation coefficient was 0.95 , the slope of the regression line was 0.95 , and the $\mathrm{y}$-axis intercept was $1.97 \mathrm{ng} / \mathrm{ml}$.

To assess further the performance of the assay, the following experiment was performed. A serum pool measuring $94 \mathrm{ng} / \mathrm{ml}$ by EMIA and RIA was spiked with $\mathrm{T}_{4}$ to a final concentration of $180 \mathrm{ng} / \mathrm{ml}$. The sample was diluted $1: 2,1: 4$, and $1: 8$ with $0.9 \% \mathrm{NaCl}$. The measured concentration of $\mathrm{T}_{4}$ titrated as a function of the spiked serum dilution (Table 4). Therefore, the test was accurate throughout the concentration range tested in this experiment (22-180 ng/ml, 0.55-4.5 ng total).

Human IgG EMIA. To demonstrate that EMIA could measure macromolecular analytes, an EMIA for human IgG was developed. A general coupling procedure (see Experimental Protocol) was used to attach human IgG $\mathrm{F}\left(\mathrm{ab}^{\prime}\right)_{2}$ fragments to liposomes. The resulting assay (Fig. 6 ), could detect concentrations of IgG between 1 and 30 $\mu \mathrm{g} / \mathrm{ml}(0.1$ and $3 \mu \mathrm{g}$ total $)$. Thirteen serum samples were obtained from a local hospital. Each sample was diluted 1000 -fold with Buffer D (see Experimental Protocol) since the concentration of $\mathrm{IgG}$ in healthy individuals ranges between 8 and $18 \mathrm{mg} / \mathrm{ml}^{16}$. The concentrations of IgG 


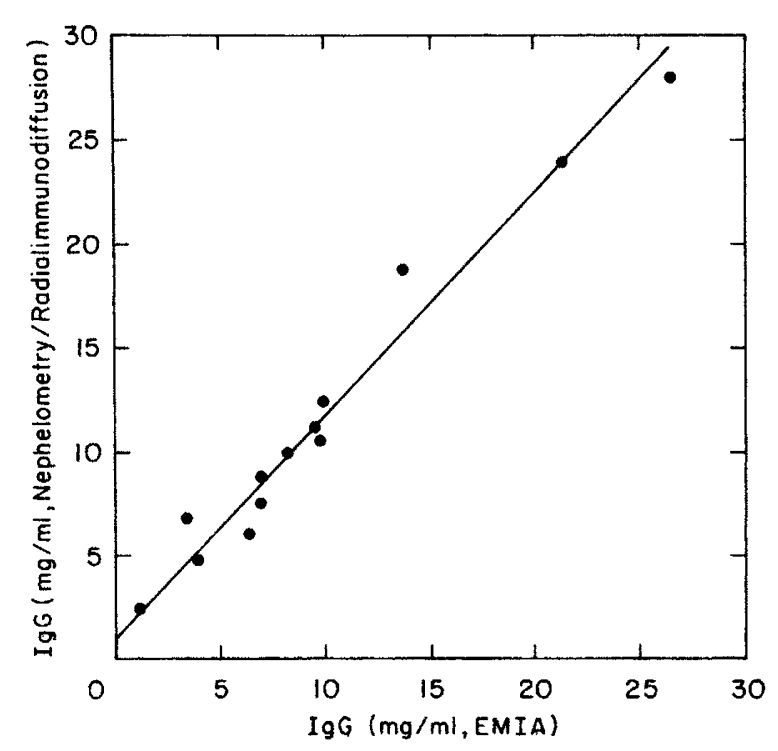

FleUn: 7 Correlation of EMIA and radialimmunodiffusion/nephelometry. Serum samples were obtained from a local hospital, where $\operatorname{lgG}$ concentrations were measured by radialimmunodiffusion or nephelometry. For measurement of the IgG concentration by EMIA, each serum sample was diluted 1000 -fold in Buffer D. $0.1 \mathrm{ml}$ of the diluted sample and the IgG standards (shown in Fig. 6) were assayed according to the procedure outlined in Figure 6 . The IgG concentration measured in each serum sample was plotted on the abcissa and that by radialimmunodiffusion or nephelometry on the ordinate.

were then determined by EMIA and compared to the concentrations measured by radialimmunodiffusion or nephelometry in the hospital laboratory. Figure 7 shows that the correlation between radialimmunodiffusion, or nephelometry, and the IgG EMIA was 0.99 , the slope of the regression line drawn through the points was 1.07 and the $y$-axis intercept was $0.91 \mathrm{mg} / \mathrm{ml}$. These results indicate excellent agreement with conventional methods for measuring human IgG.

\section{DISCUSSION}

We have described a liposome-based diagnostic technology that we call EMIA. In this system, the antigenantibody complexes that form on a liposome surface trigger the classical complement cascade. As a result, the liposome is damaged and the enzyme encapsulated within it is no longer separated from the external enzyme substrate.

Kataoka et al. ${ }^{17}$ were able to separate enzyme molecules from complement-damaged liposomes by ultracentrifugation through sucrose followed by gel filtration. We have demonstrated that the enzymatic activity unmasked by the action of complement is retained within the damaged liposomes (Table 2). We observed this result when testing liposomes with different lipid compositions and different surface antigens (D.B., unpublished data). Our findings are consistant with the results of recent experiments investigating the action of complement on resealed erythrocyte ghosts. In these experiments, even when membranes were treated with high concentrations of complement, $80 \%$ or more of an entrapped macromolecular marker remained inside the vesicles ${ }^{18-21}$.

In the EMIA system, the enzymatic activity unmasked by complement-mediated liposome damage converts a colorless substrate to a colored product. The amount of product measured reflects the extent of complementmediated liposome damage. Free antigen in a test sample competes with the antigen on the liposome surface for antibody molecules in the mixture and, as a result, reduces the number of antigen-antibody complexes that form on the liposome surface. Consequently, the amount of substrate converted to colored product is also reduced. The amount of colored product formed is inversely correlated with the amount of free antigen present in a test sample. EMIAs for thyroxine and IgG are described to demonstrate the versatility of the system.

A number of immunoassay methods employing liposomes and complement have been developed ${ }^{4-8}$. One of these, an assay for $\mathrm{T}_{4}{ }^{8}$, used a spin label as the encapsulated marker to monitor complement-mediated membrane damage. An immunoassay for theophylline ${ }^{7}$ utilized liposomes containing horseradish peroxidase. Damage was measured by following oxygen depletion with an oxygen electrode when NADH was supplied as the electron donor. The routine use of these assays in the clinical laboratory is limited because of the need for specialized equipment.

Janoff et al. ${ }^{22}$ recently described a qualitative test for systemic lupus erythematosus (SLE) utilizing liposomes entrapping the cation-responsive red dye Arsenazo III. Release of the dye, and subsequent formation of a blue complex, requires divalent cation-dependent membrane rearrangement. Sera from patients with active SLE stabilize the liposomes in the presence of divalent cations, and the red color of the vesicles is maintained. However, this type of liposome-based test is not easily applicable to the detection of other analytes.

The EMIA technology offers several advantages over current immunoassay methodologies. First, in contrast to many other liposome based tests ${ }^{4-8}$, the liposomes used in EMIA encapsulate enzyme molecules that generate a product easily detected by eye or measured with a visible light spectrophotometer. Second, in contrast to the ELISA technology ${ }^{23,24}$, EMIA employs a homogeneous phase reaction and requires only one incubation step. This makes EMIA attractive for automation. Third, in contrast to RIA, EMIA does not employ radionuclides, and eliminates the need for radioactive handling, storage, and waste disposal. Finally, in contrast to EMIT ${ }^{25}$, the EMIA technology is amenable to measuring both low molecular weight and high molecular weight analytes.

\section{EXPERIMENTAL PROTOCOL}

Buffers. Buffers employed were Buffer A: 0.02M Tris, $0.15 \mathrm{M} \mathrm{NaCl}, 0.5 \mathrm{mM} \mathrm{MgCl}_{2}, 0.15 \mathrm{mM} \mathrm{CaCl}, 3.1 \mathrm{mM}$ $\mathrm{NaN}_{3}$, pH 7.2 at $37^{\circ} \mathrm{C}$; Buffer B: $0.1 \mathrm{M}$ Tris, $0.4 \mathrm{M} \mathrm{NaCl}$, $\mathrm{pH} 8.0$ at $37^{\circ} \mathrm{C}$; Buffer $\mathrm{C}$ : $0.3 \mathrm{M}$ Tris, $0.5 \mathrm{mM} \mathrm{MgCl}_{2}$, $0.15 \mathrm{mM} \mathrm{CaCl}_{2}, 3.1 \mathrm{mM} \mathrm{NaN}_{3}, \mathrm{pH} 8.0$ at $37^{\circ} \mathrm{C}$; Buffer D: $0.15 \mathrm{M}$ Tris, $0.03 \mathrm{M} \mathrm{NaCl}, 0.5 \mathrm{mM} \mathrm{MgCl}_{2}, 0.15 \mathrm{mM} \mathrm{CaCl}_{2}$, $3.1 \mathrm{mM} \mathrm{NaN}$, pH 8.0 at $37^{\circ} \mathrm{C}$; Buffer $\mathrm{E}$ : $0.1 \mathrm{M}$ sodium acetate, $0.1 \mathrm{M} \mathrm{NaCl}, \mathrm{pH} 4.5$; and PBS: $0.01 \mathrm{M}$ sodium phosphate, $0.15 \mathrm{M} \mathrm{NaCl}, 3.1 \mathrm{mM} \mathrm{NaN}_{3}, \mathrm{pH} 7.2$ at $37^{\circ} \mathrm{C}$.

Preparation of phosphatidylethanolamine conjugates. Dipalmitoyl D,L-alpha-phosphatidylethanolamine was converted to its hemisuccinamide derivative (93\% yield) by treatment with succinic anhydride and triethylamine (1.2 equivalents each) in dimethyl formamide (DMF)/CHCl $(1: 1)$ at $60^{\circ} \mathrm{C}$ for $1 \mathrm{~h}$. After silica gel preparative thin layer chromatographic (TLC) purification using $\mathrm{CHCl}_{3}$ / $\mathrm{CH}_{3} \mathrm{OH} / \mathrm{H}_{2} \mathrm{O}(65 / 25 / 4)$ as the solvent, the hemisuccinamide group was activated with 1.2 equivalents each of ethyl chloroformate and triethylamine in $\mathrm{CHCl}_{3}$ at $5^{\circ} \mathrm{C} .0 .8$ equivalents of $\mathrm{L}$-thyroxine in an equal volume of DMF was added and allowed to react for $18 \mathrm{~h}$ at room temperature. The resulting product, a succinamide conjugate of dipalmi- 
toyl D,L-alpha-phosphatidylethanolamine and thyroxine (PEA-suc- $\mathrm{T}_{4}$ ), was isolated in $16 \%$ yield by two sequential preparative silica gel TLC purification steps using $\mathrm{CHCl}_{3} / \mathrm{CH}_{3} \mathrm{OH} / \mathrm{CH}_{3} \mathrm{COOH}(60 / 20 / 3)$ followed by $\mathrm{CHCl}_{3} / \mathrm{CH}_{3} \mathrm{OH} / \mathrm{H}_{2} \mathrm{O}(54 / 40 / 5)$ as the solvents. Further details of the synthesis of PEA-suc- $\mathrm{T}_{4}$ will be published (Myles, A., and Law, S.-L., manuscript in preparation).

Liposome preparation. $\mathrm{T}_{4}$-liposomes were prepared from a mixture of dipalmitoyl $D, L$-phosphatidylcholine (25 mg, $0.034 \mathrm{mmol}$ ), cholesterol (13.5 mg, $0.035 \mathrm{mmol}$ ), dicetyl phosphate $(1.7 \mathrm{mg}, 3.09 \mu \mathrm{mol}), \mathrm{PEA}^{-} \mathrm{suc}^{-\mathrm{T}_{4}}(0.16$ $\mathrm{mg}, 0.103 \mu \mathrm{mol})$ and 1000 units of alkaline phosphatase (Sigma Type IIIR, dialyzed against PBS and adjusted to a final concentration of 1000 units per ml) by either the vaporization method ${ }^{26-28}$ or the reverse-phase evaporation method ${ }^{29}$. The resulting liposome suspensions were incubated for five hours at room temperature and subsequently dialyzed overnight against two liters of PBS at $5^{\circ} \mathrm{C}$. Free enzyme was removed by repeated washing with PBS and centrifugation $(32,000 \times \mathrm{g}$ for 30 minutes). After the final wash the liposomes were resuspended in $3 \mathrm{ml}$ PBS and stored at $4^{\circ} \mathrm{C}$. Using the reverse-phase evaporation method, $45-50 \%$ of the phospholipid components and $15-20 \%$ of the alkaline phosphatase were recovered in the liposomes. With the vaporization method, $65-70 \%$ of the phospholipid and $5-8 \%$ of the enzyme were recovered. Liposomes prepared by either method were suitable for use in the EMIA system (data not shown).

Liposomes with 3-(2-pyridyldithio)propionyl (DTP) groups on their surface were prepared by similiar procedures from a mixture of dipalmitoyl $\mathrm{D}, \mathrm{L}$-phosphatidylcholine $(25 \mathrm{mg}, 0.034 \mathrm{mmol}$ ), cholesterol $(13.5 \mathrm{mg}, 0.035$ mmol), dipalmitoyl N-[3-(2-pyridyldithio)propionyl]-D,Lphosphatidylethanolamine $\left(0.16 \mathrm{mg}, 0.18 \mu \mathrm{mol}^{30}\right)$ and alkaline phosphatase (1000 units, Sigma Type IIIR). Human IgG liposomes were prepared by coupling human IgG $F\left(a b^{\prime}\right)_{2}$ fragments ${ }^{31}$ to these liposomes ${ }^{30,32}$. $F\left(a b^{\prime}\right)_{2}$ fragments $(1.0-2.0 \mathrm{mg} / \mathrm{ml}$ in PBS) were reacted with a 20 fold molar excess of $\mathrm{N}$-succinimidyl 3-(2-pyridyldithio) propionate for $1 \mathrm{~h}$ on ice and dialysed against Buffer $\mathrm{E}$ at $4^{\circ} \mathrm{C}$ overnight. The 2 -thiopyridyl groups were removed from the protein by reduction with $1 \mathrm{mM}$ dithiothreitol in Buffer E, followed by chromatography on Sephadex G-25 equilibrated with PBS. This reaction yielded 4-6 thiol groups per $F\left(a b^{\prime}\right)_{2}$. The thiolated $F\left(a b^{\prime}\right)_{2}$ fragments were coupled to DTP-liposomes by incubating $3.0 \mathrm{mg}$ thiolated $\mathrm{F}\left(\mathrm{ab}^{\prime}\right)_{2}$ with $1 \mathrm{ml} \mathrm{DTP}$-liposomes for $3 \mathrm{~h}$ at $37^{\circ} \mathrm{C}$. The resulting IgG liposomes were washed as described above, then resuspended in $1 \mathrm{ml}$ PBS. Using this procedure liposome preparations containing $60-100 \mu \mathrm{g} F\left(\mathrm{ab}^{\prime}\right)_{2}$ per $\mathrm{ml}$ liposomes were obtained.

Antisera and Complement. Lyophilized guinea pig complement (Grand Island Biological Company) was routinely dissolved in Buffer $\mathrm{A}$ and stored in $1 \mathrm{ml}$ aliquots at $-20^{\circ} \mathrm{C}$. Rabbit anti-human IgG serum was obtained from Miles Laboratories. Lyophilized sheep anti- $\mathrm{T}_{4}$ serum (Benenden Chest Hospital, Cranbrook, Kent, England) was dissolved in deionized $\mathrm{H}_{2} \mathrm{O}$ and stored in $0.1 \mathrm{ml}$ aliquots at $-20^{\circ} \mathrm{C}, \mathrm{T}_{4}$ radioimmunoassay kits (Tetra Tab) were purchased from Clinical Assays Inc.

\section{Acknowledgments}

The authors wish to thank S.-J. Law for providing intermediates used for liposome synthesis; G. Akots, T. Delizza, K. Hsiao, and J. Linker for expert technical assistance; David Botstein for many helpful suggestions; and M. Cole for typing the manuscript.

Received 12 December 1983; accepted 1 February 1984.
References

1. Kinsky, S. C. 1972. Antibody-complement interaction with lipid model membranes. Biochim. Biophys. Acta 265:1-23.

2. Haxby, J. A., Kinsky, C. B., and Kinsky, S. C. 1968. Immune response of a liposomal model membrane. Biochemistry 61:300-307.

3. Kinsky, S. C., Haxby, J. A., Zopf, D. A., Alving, C. R., and Kinsky, C. B. 1969. Complement-dependent damage to liposomes prepared from pure lipids and Forssman hapten. Biochemistry 8:4149-4158.

4. Wei, R., Alving, C. R., Richards, R. L., and Copeland, E. S. 1975. Liposome spin immunoassay: A new sensitive method for detecting lipid substances in aqueous media. J. Immunol. Meth. 9:165-170.

5. Rosenqvist, E. and Vistnes, A. I. 1977. Immune lysis of spin label loaded liposomes incorporating cardiolipin: A new sensitive method for detecting anticardiolipin antibodies in syphilis serology. J. Immunol. Meth. 15:147-155.

6. Chan, S. W., Tan, C-T., and Hsia, J. C. 1978. Spin membrane immunoassay: Simplicity and specificity. J. Immunol. Meth. 21:185-195.

7. Haga, M., Itagaki, H. and Sugawara, S. 1980. Liposome immunosensor for theophylline. Biochem. Biophys. Res. Comm. 95:187-192.

8. Tan, C.-T., Chan, S. W, and Hsia, J. C. 1981. Membrane immunoassay: A spin membrane immunoassay for thyroxine. Meth. Enzymol. 74:152-161.

9. Cole, F. X. 1982. U.S. Patent \#4,342,826

10. Alving, C. R., Kinsky, S. C., Haxby, J. A., and Kinsky, C. B. 1969. Antibody binding and complement fixation by a liposomal model membrane. Biochemistry 8:1582-1587.

11. Inoue, K., Kataoka, T., and Kinsky, S. C. 1971. Comparative responses of liposomes prepared with different ceramide antigens to antibody and complement. Biochemistry 10:2574-2581.

12. Mayer, M. M. 1967. Complement and complement fixation. In $\mathbf{E x}$ perimental Immunochemistry, 2nd ed. E. A. Kabat and M. M. Mayer (eds.), C. C. Thomas, Springfield.

13. Eisen, H. N. 1980. Antibody-antigen reactions, p. 297-336. In Microbiology. Davis, B. D., Dulbecco, R., Eisen, H. N., and Ginsberg, H. S. (eds.), Harper and Row, Hagerstown.

14. Clinical assays technical bulletin. 1982. GammaCoat $\left[{ }^{125} \mathrm{I}\right]$ free/total $T_{4}$ radioimmunoassay, p. 19.

15. Means, G. E., and Feeney, R. E. 1971. Special problems in analysis of chemically modified proteins, p. 55-65. In Chemical Modification of Proteins. Halden-Day, Inc., San Francisco.

16. Ritzmann, S. E. 1982. Immunoglobulin abnormalities, p. 365. In Serum Protein Abnormalities. Ritzmann, S. E. and Daniels, J. C. (eds.), Alan R. Liss, Inc, New York.

17. Kataoka, T., Williamson, J. R., and Kinsky, S. C. 1973. Release of macromolecular markers (enzymes) from liposomes treated with antibody and complement: An attempt at correlation with electron microscopic observations. Biochim. Biophys. Acta 298:158-179.

18. Sims, P. J, and Lauf, P. K. 1978. Steady-state analysis of tracer exchange across the C5b-9 complement lesion in a biological membrane. Proc. Natl. Acad. Sci. U.S.A. 75:5669-5673.

19. Giavedoni, E. B., Chow, Y. M., and Dalmasso, A. P. 1979. The func tional size of the primary complement lesion in resealed erythrocyte membrane ghosts. I. Immunol. 122:240-245.

20. Sims, P. J. and Lauf, P. K. 1980. Analysis of solute diffusion across the C5b-9 membrane lesion of complement: Evidence that individual C5b-9 complexes do not function as discrete, uniform pores. J. Immunol. 125:2617-2625.

21. Ramm, L. E., Whitlow, M. B., and Mayer, M. M. 1983. Size distribution and stability of the trans-membrane channels formed by complement complex C5b-9. Molec. Immun. 20:155-160.

22. Janoff, A. S., Carpenter-Green, S., and Ostro, M. J. 1983. A novel liposome composition for a rapid colorimetric test for systemic lupus erythematosis. Clin. Chem. 29:1587-1592.

23. Schuurs, A. H. W. M. and Van Weemen, B. K. 1977. Enzyme-immunoassay. Clin. Chim. Acta 81:1-40.

24. Ngo, T. T. and Lenhoff, H. M. 1982. Enzymes as versatile labels and signal amplifiers for monitoring immunochemical reactions. Molecular and Cellular Biochemistry 44:3-12.

25. Engvall, E. 1980. Enzyme immunoassay ELISA and EMIT. Meth. Enzymol. 70:419-439.

26. Deamer, D. and Bangham, A. D. 1976. Large volume liposomes by an ether vaporization method. Biochim. Biophys. Acta 443:629-634.

27. Schieren, H. Rudolph, S., Finkelstein, M., Colman, P., and Weiss mann, G. 1978. Comparison of large unilamellar vesicles prepared by a petroleum ether vaporization method with multilamellar vesicles. Biochim. Biophys. Acta 542:137-153.

28. Cafiso, D. S., Petty, H. R., and McConnell, H. M. 1981. Preparation of unilamellar lipid vesicles at $37^{\circ} \mathrm{C}$ by vaporization methods. Biochim. Biophys. Acta. 649:129-132.

29. Szoka, F., Jr. and Papahadjopoulos, D. 1978. Procedure for preparation of liposomes with large internal aqueous space and high capture by reverse-phase evaporation. Proc. Nat. Acad. Sci. U.S.A. 75:41944198 .

30. Garvey, J. S., Cremer, N. E., and Sussdorf, D. H. 1977. Subunits of IgG, p. 263. In Methods in Immunology, 3rd ed. Benjamin/Cummings, Reading, MA.

31. Leserman, L. D., Barbet, J., and Kourilsky, F. 1980. Targeting to cells of fuorescent liposomes covalently coupled with monoclonal antibody or protein A. Nature 288:602-604.

32. Martin, F. J., Hubbell, W. L., and Papahadjopoulos, D. 1981. Immunospecific targeting of liposomes to cells: A novel and efficient method for covalent attachment of Fab' fragments via disulfide bonds. Biochemistry 20:4229-4238. 